\title{
CONTINUING VIOLATIONS, DISPARATE IMPACT IN COMPENSATION, AND OTHER TITLE VII ISSUES
}

\section{DOUglas Laycock*}

When I teach the course in Employment Discrimination, some students think that I am a knee-jerk liberal and some think that I am a hopeless reactionary. I guess that makes me a radical centrist. I think $I$ am just following the nondiscrimination principle wherever it leads. In any event, I will not discriminate today; I will throw a few rocks at each side.

\section{Pendent State Claims}

The article by Brooks, McGinn, and Caryl demonstrates strong advocacy skills and careful case analysis. But with all respect, two-thirds of that paper is simply obstructionist. Procedural and jurisdictional rules should be implemented to secure just and inexpensive determinations on the merits. Their proposals concerning pendent state claims and attorneys' fees are designed to get rid of impecunious plaintiffs without reaching the merits.

The consequence of restricting pendent jurisdiction is that most pendent state claims will never be filed. Many plaintiffs cannot afford to try two lawsuits instead of one; Dan McGinn acknowledged as much when he presented the article orally. Plaintiffs who can afford two suits will often decide that it is not worth their effort to file the second claim in a state court they think is less sympathetic than the federal court. The primary motive for objecting to pendent jurisdiction is surely the desire to make these claims go away without decision on the merits. Defense counsel may be obligated to make the argument, but courts need not take it seriously.

\section{II \\ “Double” Attorneys' Fees}

The complaint about attorneys' fees appears to be that defendants cannot afford to pay defense counsel and then also pay plaintiffs' counsel if they are found to have discriminated. The implicitly proposed solution is that they

\footnotetext{
Copyright $@ 1986$ by Law and Contemporary Problems

* Fulbright \& Jaworski Professor and Associate Dean for Academic Affairs, University of Texas at Austin School of Law.

1. Brooks, McGinn \& Cary, Second Generation Problems Facing Employers in Employment Discrimination Cases: Continuing Violations, Pendent State Claims, and Double Attorneys' Fees, Law \& Contemp. Probs., Autumn 1986, at 27.
} 
should not be required to pay plaintiffs' counsel, or at least that they should not pay him much. It is equally plausible to suggest that they should not pay their own counsel so much. Defendants can save money either way.

The problem is not the fee shifting provision. Without it, Title VII would be almost wholly unenforceable. The problem is the price of legal services. Litigation is labor intensive, and it is hard to provide labor intensive services with $\$ 150$-an-hour labor. Plaintiffs' fee awards are too high because defense counsel charge too much. Defense lawyers set the market rate on which plaintiffs' fee awards are based. Plaintiffs' counsel rarely bill by the hour; they generally work for contingent fees and for fee awards that are inherently contingent. So if fee awards are too high, defendants and their lawyers can largely blame themselves.

III

\section{Disparate Impact Claims of Sex Discrimination in Compensation}

Many of the cases in Barbara Norris' article ${ }^{2}$ involve sex discrimination in compensation. In some of those cases, plaintiffs relied on disparate impact theory. Norris suggests that plaintiffs routinely invoke both disparate treatment and disparate impact theories, challenging employers to validate any allegedly nondiscriminatory explanations of apparent differences in the pay of men and women.

Defense counsel in these cases may be overlooking their strongest response. There is no disparate impact liability in sex discrimination in compensation cases. The Supreme Court so held in City of Los Angeles $v$. Manhart. ${ }^{3}$ That is why men could not complain that equal pensions for individuals disadvantaged them as a group. In County of Washington v. Gunther, ${ }^{4}$ the Court held that the four exceptions to the Equal Pay Act are incorporated into Title VII by the Bennett Amendment. ${ }^{5}$ Gunther does not cite Manhart, but it independently implies that the fourth exception precludes disparate impact liability. ${ }^{6}$ The majority opinion was struggling to explain how the Equal Pay Act exceptions are broader than the Title VII exceptions. The obvious answer is that the Equal Pay Act precludes disparate impact liability, and the opinion would have been more persuasive if it had said so explicitly. Justice Brennan said as much as he could without actually giving this answer.

Many plaintiffs' advocates believe that disparate impact theory protects women and minorities only and is unavailable to white males. That theory could explain the result in Manhart, but it cannot explain the opinions in

2. Norris, A Structural Approach to Evaluation of Multiple Regression Analysis as Used to Prove Employment Discrimination: The Plaintiff's Answer to Defense Attacks of "Missing Factors" and "Pre-Act Discrimination," LaW \& Contemp. Probs., Autumn 1986, at 65.

3. 435 U.S. 702,710 n.20, 713 n.24 (1978).

4. 452 U.S. 161 (1981).

5. Id. at 171 .

6. See id. at 170-71. 
Manhart and Gunther. More important, that theory cannot explain the fourth exception to the Equal Pay Act. Here is the key sentence with the excess verbiage stripped away: "No employer . . . shall discriminate . . . on the basis of sex . . . except where ... (iv) . . . based on any . . . factor other than sex."7 The prohibition and the exception appear identical. The sentence is incomprehensible unless the prohibition forbids disparate treatment and the exception authorizes disparate impact. The legislative history is perfectly clear that disparate impact is exactly what the fourth exception was intended to authorize. ${ }^{8}$

\section{IV}

\section{Continuing Violations}

Both Barbara Norris' article and the Brooks, McGinn, and Cary article discuss continuing violations. Both sides have some legitimate complaints. The continuing violation concept is not as difficult and complex as courts and litigants have made it in Title VII cases. The confusion derives from many sources.

Part of the problem is that this debate has been carried on in a Title VII vacuum, without regard to continuing violation law in other substantive areas. There is a well-developed continuing violation jurisprudence, especially in antitrust law, and Title VII lawyers ought to look at it. The other cases are not entirely free of confusion either, but they are in better shape than the Title VII cases, and some of them were decided by the Supreme Court.

The classic example of a continuing violation is Hanover Shoe, Inc. v. United Shoe Machinery Corp. ${ }^{9}$ Hanover filed suit in 1955, alleging that United's restrictive system of distributing shoe machinery violated the antitrust laws. United argued that the claim was barred by limitations because it had applied the challenged policy to Hanover since 1912. Obviously, United should not be able to continue its illegal conduct forever because no one challenged it during World War I. Almost as obviously, Hanover should not be able to collect forty years of damages with prejudgment interest. The Court thought it clear that Hanover could sue, but that it could recover only those damages suffered within the period of limitations. This is the day-by-day rule: a new cause of action accrues each day defendant violates the law.

Hanover noted not only that the defendant continuously violated the antitrust laws, but that these violations "inflicted continuing and accumulating harm."'10 Three distinct requirements are tucked into that formulation: the

7. 29 U.S.C. $\$ 206(d)(1)$ (1982).

8. See Brilmayer, Hekeler, Laycock \& Sullivan, Sex Discrimination in Employer-Sponsored Insurance Plans: A Legal and Demographic Analysis, 47 U. CHI. L. REv. 505, $516-21$ (1980) (detailed analysis of the Equal Pay Act and its legislative history); see also Kouba v. Allstate Ins. Co., 691 F.2d 873 (9th Cir. 1982) (grappling with, but not fully resolving, the difficulties in the Equal Pay Act language).

9. 392 U.S. 481 (1968).

10. Id. at 502 n.15. 
violation must continue, the harm must continue, and the continuing violation must cause the harm. ${ }^{11}$

There is another line of cases in the lower courts and some of the state courts. Those cases hold that if a continuing violation continues into the limitations period, and if it is difficult or impossible to separate the damages and allocate discrete items of damage to particular times, then the plaintiff can recover all the damages ever caused by the violation without regard to the limitations period. I will call this the "cumulative recovery rule."

Railing v. United Mine Workers ${ }^{12}$ illustrates the cumulative recovery rule. Railing involved an illegal strike accompanied by serious violence. The strike lasted sixteen months instead of forty years, which is typical of cumulative recovery cases; they tend to involve short violations.

The cumulative recovery theory is inapplicable to back pay claims, because it is easy to allocate lost pay to particular pay periods within or without the limitations period. But not surprisingly, some courts have applied the cumulative recovery theory in cases in which damages were not inseparable. The Seventh Circuit recently cited cumulative recovery cases and day-by-day cases seemingly without noticing the difference between them, concluding that they all support the "general rule" of cumulative recovery. ${ }^{13}$ My sense of the cases is that the day-by-day rule greatly predominates; that is certainly true of the Supreme Court decisions.

The debate over continuing violations in Title VII cases has been much messier. One source of confusion arises from the fact that the 180-day statute of limitations ${ }^{14}$ is too short-absurdly short given the relatively unsophisticated class the statute is intended to protect. The harsh statute of limitations was one of the compromises required to pass Title VII, but after the fact it begins to look like an unprincipled obstacle to enforcement. The short statute has created pressure to evade it, and evasions always confuse the law.

A second source of confusion is the now rejected theory that the statute of limitations is not a statute of limitations at all, but a jurisdictional prerequisite not subject to the usual tolling rules. I have always considered that argument frivolous. Jurisdictional rules allocate authority to decide among tribunals. The 180-day time limit on filing does not allocate the dispute to another tribunal; it cuts off a plaintiff's rights altogether if he does not file within a stated time period. That result almost defines a statute of limitations, and in 1982 the Supreme Court finally held the 180-day limit to be a statute of

11. For a clear statement and analysis of these three requirements in a non-Title-VII race discrimination case, see Baker v. F \& F Inv. Co., 489 F.2d 829 (7th Cir. 1973). Another Supreme Court antitrust case applying the day-by-day rule is Zenith Radio Corp. v. Hazeltine Research, Inc., 401 U.S. 321 (1971).

12. 429 F.2d 780, 782-83 (4th Cir. 1970), vacated, 401 U.S. 486 (1971). On remand from the Supreme Court, the court of appeals applied the day-by-day rule. Railing v. United Mine Workers, 445 F.2d 353 (4th Cir. 1971).

13. Taylor v. Meirick, 712 F.2d 1112, 1118-19 (7th Cir. 1983)

14. 42 U.S.C. $\$ 2000 \mathrm{e}-5(\mathrm{e})(1982)$. 
limitations. ${ }^{15}$ The jurisdictional argument is finally dead, but it distorted the development of limitations law for most of Title VII's history. The argument increased the pressure to avoid the statute of limitations and reduced the number of tools available to evade the statute.

A third source of confusion is the theory, also now rejected, that continuing effects of past violations are actionable. ${ }^{16}$ Continuing effects of a past violation may sound like a continuing violation, but the two concepts are wholly different. If I run over a student with my car, the effects may last for the rest of his life. If he is paralyzed, he will probably be just as paralyzed at age eighty as he was at age twenty. No jurisdiction has ever thought he could sue me at any time in that sixty-year period. My violation of the law would be over in an instant of negligence, and the statute of limitations would run from that instant. Whatever the moral force of the argument that Congress should have tried to undo the effects of past discrimination, that argument has no basis in continuing violation theory. The continuing-effects-of-past-violations theory was created specially for discrimination law; I know of no precedent in any other substantive area.

Once the continuing effects theory was created, it inevitably spread confusion. When the Supreme Court repudiated the continuing effects theory in International Brotherhood of Teamsters $v$. United States, ${ }^{17}$ the confusion was multiplied. Many lawyers and judges incorrectly thought the Court had held that there could be no continuing violation under Title VII. Other lawyers tried to revive the continuing effects theory by describing all effects as current violations.

The congressional response to the continuing effects theory introduced a fourth source of confusion. Faced with courts prepared to impose liability for acts of discrimination outside the period of limitations, Congress imposed a separate time limit on back pay liability. The 1972 amendments inserted a clause in section $706(\mathrm{~g})$ of Title VII providing that courts should not award back pay for any period more than two years before the filing of a charge. ${ }^{18}$ The continuing effects theory that brought forth the amendment is now gone. The amendment is still with us, but it no longer makes sense. Normally, a 180-day statute of limitations would mean that plaintiffs could not recover back pay for any period more than 180 days prior to the filing of a charge, even if there were a continuing violation. In the context of continuing violations, there is no good way to reconcile a 180 -day limitations period with a two-year back pay period, but courts and litigants have to grapple with the problem.

15. Zipes v. Trans World Airlines, 455 U.S. 385 (1982). A similar debate continues with respect to a 30-day limitations period governing discrimination suits by federal employees. See Cooper v. United States Postal Serv., 471 U.S. 1022, 1023 (1985) (White, J., dissenting from denial of certiorari).

16. The theory originated in Quarles v. Philip Morris, Inc., 279 F. Supp. 505 (E.D. Va. 1968). It was definitively rejected in International Bhd. of Teamsters v. United States, 431 U.S. 324 (1977).

17. 431 U.S. 324 (1977).

18. 42 U.S.C. $\$ 2000 \mathrm{e}-5(\mathrm{~g})(1982)$. 
A leading treatise argues that the two-year back pay period implies that Congress intended the cumulative recovery rule for continuing violations, subject to an absolute limit of two years. ${ }^{19}$ That argument is one way of giving content to each clause of the statute, but it ignores the origins of the two-year back pay clause. Congress was responding to the continuing effects theory; there is no evidence the legislature had ever heard of the choice between the cumulative recovery and day-by-day versions of continuing violation theory.

There is a better way to give effect to both the 180-day limitations clause and the two-year back pay clause. In cases of fraudulent concealment and estoppel, statutes of limitations may be tolled indefinitely. In those cases, the statute of limitations does not run anew from each day's violation; it never begins to run until the concealment or estoppel ends. ${ }^{20}$ The two-year back pay clause can put a meaningful outside limit on recovery in those cases. Congress probably was not thinking about those cases either, but this interpretation has the virtue of giving a meaning to the language that is consistent with general principles of limitations law and not inconsistent with what Congress was thinking about. The two-year limit should have been applied to fraudulent concealment and estoppel even if the continuing effects theory had survived.

A fifth source of confusion is that the distinction between effects and violations must often be worked out in the context of statistical techniques that many lawyers and judges barely understand. Few defense lawyers would openly say that an employer can forever discriminate as much as he wants against any employee hired before the effective date of Title VII. Yet that is what a defense lawyer says when he argues that persons hired before 1972 must be excluded from a statistical analysis of pay discrimination in 1984 . Norris tells us that a judge made that mistake in Sobel $v$. Yeshiva University. ${ }^{21}$ That is one way to read the opinion; my view is that he made a different mistake-more defensible, but still a mistake-which is discussed below.

The final source of confusion is the least avoidable: employment disputes present some cases in which it is genuinely difficult to distinguish continuing violations from continuing effects. Courts have taken the view that a discharge is a completed violation. ${ }^{22}$ This view predates Title VII; it is also the law of the National Labor Relations Board (NLRB). ${ }^{23}$ The rationale in the Supreme Court's Title VII cases seems to be that the violation consists of a one-time decision and that plaintiff should sue as soon as he learns of the

19. C. Sullivan, M. Zimmer \& R. Richards, Federal Statutory Law of Employment Discrimination $\$ 3.5$, at 276 (1980).

20. For examples of fraudulent concealment, see Marcus, Fraudulent Concealment in Federal Court: Toward a More Disparate Standard?, 71 GEO. L.J. 829, 830-33 (1983). For examples of estoppel to assert limitations, see Glus v. Brooklyn E. Dist. Terminal, 359 U.S. 231 (1959); Bomba v. W.L. Belvidere, Inc., 579 F.2d 1067 (7th Cir. 1978).

21. 566 F. Supp. 1166 (S.D.N.Y. 1983).

22. E.g., United Air Lines, Inc. v. Evans, 431 U.S. 553 (1977).

23. E.g., NLRB v. Textile Machine Works, Inc., 214 F.2d 929 (3d Cir. 1954). 
decision. ${ }^{24}$ Setting aside the question whether limitations should run from the day plaintiff learns of the decision or from the last day he worked, the view that a discharge is not a continuing violation is probably correct.

Some refusals to hire are similar to discharges for limitations purposes; some are different. Limitations should run from the date a plaintiff was rejected if he were arguably rejected because of an individualized decision about him or about circumstances at the time of the event. The result should sometimes be different, however, when the plaintiff reapplies later and gets rejected again. If the employer makes a new and independent decision to reject him, there is no reason not to start the limitations period running again. Under the day-by-day rule, back pay would accrue from the date of the second rejection, not the time-barred first rejection. If, instead, the employer rejects a reapplying plaintiff on "res judicata" grounds, it is certainly plausible to conclude that the plaintiff should not be allowed to renew the old dispute by filing a new and foredoomed application. Courts have applied such a distinction between new decisions and reliance on old decisions in NLRB cases in which a dischargee applies for reemployment as a new hire. ${ }^{25}$ This view has much to recommend it where the reason for the original rejection is disputed. Evidence of the employer's original motive will be just as stale, whether or not the employee reapplied within the period of limitations.

However, if the plaintiff were rejected because of an openly stated and continuing policy, there is strong reason to conclude that the employer committed a new act of discrimination each time he applied that policy. The issue will be the legality of the fixed policy, not the employer's one-time motive, so there is no reason in limitations policy to override the commonsense view that the employer discriminated every time he rejected an applicant for a discriminatory reason. Indeed, I think the violation continues whether or not the plaintiff reapplies. The policy is a violation, and it prevents the plaintiff's employment for as long is it continues. Every day, the illegal policy bars the plaintiff from successfully applying for employment. ${ }^{26}$ The causal link between the violation and the harm to plaintiff might be broken if plaintiff loses interest in the job, but that should not be irrebuttably presumed. The plaintiff should be allowed to show that he reapplied, or that he would have reapplied but for the policy. He should be allowed to show this even if he were previously discharged.

Consider United Airlines, Inc. v. Evans. ${ }^{27}$ Evans was discharged because of a rule that female flight attendants could not be married. The discharge was an immediately completed violation, and her claim for reinstatement with seniority was barred 180 days later. The 180-day limitation should be irrelevant, however, to a claim that she would have reapplied but for the

24. Delaware State College v. Ricks, 449 U.S. 250 (1980).

25. E.g., NLRB v. Southern Plasma Corp., 626 F.2d 1287 (5th Cir. 1980).

26. It is settled that a plaintiff is entitled to relief if discrimination deterred him from applying. See International Bhd. of Teamsters v. United States, 431 U.S. 324, 362-67 (1977).

27. 431 U.S. 553 (1977). 
continuing discriminatory policy. She should be able to file that claim any time up to $\mathbf{1 8 0}$ days after the end of the policy. But the remedy for that violation would not be reinstatement with her original seniority; neither back pay nor seniority could go back more than $\mathbf{1 8 0}$ days before she filed a charge.

Now consider another variation: job assignment claims. A claim that plaintiff was hired as an administrative secretary when she was qualified to be a management trainee looks very much like a claim that her application to be a management trainee was rejected. It is easy to imagine the present Supreme Court saying the violation was completed when the employer decided to hire her as an administrative secretary. But a discriminatory job assignment is more than just a refusal to hire. It is equally plausible to find a new violation every day. Every day, she reports to work with the skills to be a management trainee and is instead given work and pay as an administrative secretary. She is continuously underutilized and underpaid because of her sex. At least one of the airline cases so holds, finding a continuing violation against stewardesses who accepted reassignment to ground duty because of rules against motherhood. ${ }^{28}$ As in the discharge cases, it is easier to find a continuing violation when the job assignment is compelled by a continuing policy than when it results from a one-time judgment about the employee's credentials or work performance. At least one court has rejected a claim that the latter kind of job reassignment is a continuing violation. ${ }^{29}$

Finally, there are the pay cases. It seems clear that pay discrimination is a continuing violation. Every pay period, the plaintiff performs new services and gets a new paycheck. If that paycheck is reduced because of race or sex, that is a new act of discrimination. A plaintiff should be able to file a charge at any time, recover back pay for the last 180 days, and obtain an injunction against future violations.

As usual, there is a counterargument. If we carry the Supreme Court's discharge cases to their logical conclusion, the pay violation consists of the employer's decision to set the plaintiff's salary. That decision is the violation, and all pay claims are barred 180 days later. As I read the opinion, that is what the judge held in Sobel $v$. Yeshiva University. ${ }^{30} \mathrm{He}$ refused to consider what the plaintiffs were paid, and examined only their recent raises. He found that men and women had received equal annual raises since the statute took effect. He thought that meant the employer had complied with the statute, even if it were paying women much less than similarly situated men. The discrepancy resulted from a pre-1972 decision that was not illegal when it was made.

I understand the series of logical steps by which a court might reach that decision, but that logic ignores both reality and the statutory policy. If it becomes settled law, it will mean that employers can discriminate forever

28. In re Consolidated Pretrial Proceedings in the Airline Cases, 582 F.2d 1142 (7th Cir. 1978), rev'd on other grounds sub nom. Zipes v. Trans World Airlines, Inc., 455 U.S. 385 (1982).

29. Trabucco v. Delta Airlines, 590 F.2d 315 (6th Cir. 1979).

30. 566 F. Supp. 1166 (S.D.N.Y. 1983). 
against victims of pay discrimination who fail to file a charge within 180 days of the first pay decision. All the employer need do is add equal raises to unequal starting salaries; the salaries will always be unequal. That cannot be the law: unequal current pay for current work is a current violation. If Sobel were good law, then City of Los Angeles v. Manhart, ${ }^{31}$ Arizona Governing Committee $v$. Norris, ${ }^{32}$ and all the other pension cases were time-barred. The decision to create discriminatory pension plans in those cases was made long before the charge, even though contributions were being made currently and benefits to the named plaintiffs had not even begun.

The issue of equal raises added to an unequal base is now squarely before the Supreme Court in a case that the Fourth Circuit got squarely wrong. ${ }^{33}$ The Fourth Circuit relied on cases that rejected belated challenges to the continuing effects of seniority classifications. Those cases are not analogous. An employee's place on a seniority roster is a status to which contractually specified rights attach at the moment of placement. Seniority rights are rarely renegotiated, but pay is set anew in every contract period. There is nothing inevitable, or even legitimately foreseeable, about openly perpetuated pay discrimination. The Fourth Circuit has held that claims for present and future pay discrimination were time-barred years ago. Let us hope the Supreme Court does better.

I have suggested some fine distinctions, and there is room to argue with some of them. I think there is much less room to argue with the method I have employed. It is the only way to make sense of continuing violation cases. Each of my distinctions is based on a careful attempt to identify each possible violation, decide whether any of those violations occurred within 180 days of the charge, and then measure the harm flowing from those violations that occurred within the 180-day period.

\section{POSTSCRIPT}

While this article was in page proof, the Supreme Court resolved the issue of equal raises added to an unequal base. ${ }^{34}$ The Court unanimously reversed the Fourth Circuit. ${ }^{35}$ The Court correctly concluded that "[e]ach week's pay check that delivers less to a black than to a similarly situated white is a wrong actionable under Title VII."36

31. 435 U.S. 702 (1978).

32. 463 U.S. 1073 (1983).

33. Bazemore v. Friday, 751 F.2d 662 (4th Cir. 1984), cert. granted, 106 S. Ct. 379 (1985).

34. Bazemore v. Friday, 106 S. Ct. 3000, 3006-07 (1986).

35. 751 F.2d 662 (4th Cir. 1984). See supra text accompanying note 33.

36. $106 \mathrm{~S}$. Ct. at 3006 . 
